\begin{tabular}{|c|c|c|}
\hline & $\begin{array}{c}\text { International Journal of Current Research in } \\
\text { Biosciences and Plant Biology } \\
\text { EXCELLENT } \\
\text { PUBLISHERS }\end{array}$ \\
Volume $4 \bullet$ Number 7 (July-2017) $・$ ISSN: 2349-8080 (Online) \\
Journal homepage: www.ijcrbp.com
\end{tabular}

\title{
Exploration of a Hyphomycetes Fungus for Biological Control of Horse Purslane Weed in India
}

\author{
Gaddeyya Gandipilli*, Geddada Esteru Rani, P. K. Ratna Kumar
}

Centre of Advanced Study (UGC-SAP-CAS-I), Department of Botany, College of Science \& Technology, Andhra University, India

*Corresponding author.

\begin{tabular}{|c|c|}
\hline Abstract & Article Info \\
\hline \multirow{11}{*}{$\begin{array}{l}\text { Trianthema portulacastrum L., commonly known as desert horse purslane is a member } \\
\text { of Aizoaceae, interfere with many economic crops and treated as one of the serious } \\
\text { weed in India and around the world. It is a native plant of South Africa but widely } \\
\text { distributed in India, Sri Lanka, Pakistan and many parts of the world. It has become a } \\
\text { noxious weed due to competition for yields in many crops and causing significant } \\
\text { reduction in the yield. For instance, its infestation in cotton, maize and direct-seeded } \\
\text { rice reduce crop yields by } 32-60 \% \text {, up to } 60-70 \% \text { infestation of this weed has been } \\
\text { reported in pigeon pea and soybean fields and } 80-90 \% \text { in maize and brassica fields. The } \\
\text { common weed control methods such as cultural practises, mechanical and herbicide } \\
\text { treatments does not consider for the effective management of this weed due to their } \\
\text { failures. Recently, the successes of Biological control agents over many herbs and alien } \\
\text { weeds attracted researchers with their eco-friendly tactics. Therefore, a systematic field } \\
\text { study was conducted for preliminary screening of natural enemies against horse } \\
\text { purslane weed which would be an effective biocontrol agent after extensive work. An } \\
\text { ascomycetes fungus, Gibbago trianthemae Simmons was isolated from parasitized } \\
\text { leaves of horse purslane and the identity was confirmed by relevant literature and the } \\
\text { biocontrol potential of the pathogen evaluated. }\end{array}$} & $\begin{array}{l}\text { Accepted: } 28 \text { June } 2017 \\
\text { Available Online: 06 July } 2017\end{array}$ \\
\hline & Keywords \\
\hline & Biological control \\
\hline & Gibbago trianthemae Simmons \\
\hline & Mycoherbicide \\
\hline & Trianthema portulacastrum $\mathrm{L}$. \\
\hline & \\
\hline & \\
\hline & \\
\hline & \\
\hline & \\
\hline
\end{tabular}

\section{Introduction}

Weeds are unwanted plants growing along with domesticated crops. They are non-indigenous plants that can invade or negatively alter native plant communities. Weed plants grow faster, spread rapidly, reproduce in high numbers and produce large quantities of seeds which enable them to establish a kingdom of their own within a short period of time (Dangwal et al., 2010). They always act as energy drains in the entire managed ecosystem such as agricultural fields, forestry, horticulture, aquaculture, etc. They decrease the yield of crops by competing for water, nutrients, space, $\mathrm{CO}_{2}$ and sunlight. They provide habitat for harmful insects and may act as alternate host for pathogens and other organisms (Peters, 1955). Weeds show allelopathic effects on agricultural crops by secreting allelochemicals that inhibit the growth and germination of agricultural crops. These weeds effectively compete with the crop for nutrients, water, and space and reduce the yield ranging from 12 to $51 \%$ (Rao and Singh, 1997; Mukharjee and Singh, 2005; Halder and Patra, 2007). 
Trianthema portulacastrum L. (Family: Aizoaceae) is one of the serious weeds of India. It is known as Hand Qooqi in Arabic, Dewasapt in Persian and Horse purslane in English. It is an annual herb which spreads on the ground in circle and not more than 4-6 ft in length, commonly found in moist soil and near the river and pond. The plant is found in tropical and subtropical countries of the world, and almost throughout India as a weed in cultivated and wastelands (Ghani, 1929; Kirtikar and Basu, 2003). Trianthema portulacastrum L. is an annual indigenous plant of South Africa. It is widely distributed in South East and West Asia, Africa and Tropical America and extensively distributed in India, Srilanka, Baluchistan and it is one of the serious weeds of maize, sugarcane, cotton and summer vegetables in Pakistan (Kirtikar and Basu, 2003; Nayyar et al., 2001). In India and neighbouring countries, it is among the most common weeds during summer season in the major field crops such as pulses, cotton, sugarcane, direct-seeded rice and maize. Its infestation in cotton, maize and direct-seeded rice especially in rainy season is a matter of great concern and could reduce crop yields by 32-60\% (Baylan and Malik, 1989). In India, horse purslane has been reported in the states of Uttar Pradesh, Punjab, Haryana, Rajasthan and Delhi and considered as a number one problematic terrestrial weed by virtue of its infestation in various agricultural and vegetable crops such as mustard, maize, pigeon pea, mung bean, potato, onion, cotton, soybean, pearl millet and sugarcane, especially during the rainy seasons (Balyan and Bhan, 1986).

Horse purslane is an introduced terrestrial weed in India but it has become a noxious weed due to competition for yields in various agricultural and vegetable crops such as mustard, maize, pigeon pea, soybean, potato and onion crops in Northern India. Up to $60-70 \%$ infestation of this weed has been reported in pigeon pea and soybean fields and $80-90 \%$ in maize and brassica fields (Aneja et al., 2000). Even though horse purslane causes heavy losses in yield of many agricultural crops there is no any sufficient information available for weed control. Hence, a systematic field study was conducted at Visakhapatnam District, Andhra Pradesh to explore biocontrol agents against horse purslane weed.

\section{Materials and methods}

\section{Field study and sample collection}

The field observations on invasion of horse purslane were conducted in different agricultural crops classifieds as food crops, pulses, vegetable crops, oil crops and commercial crops at Vishakhapatnam District. Taxonomical features of the weed were identified using relevant literature (Gamble, 1918; Pullaiah and Chennaiah, 1997; Kirtikar and Basu, 2003).The weed infestation was studied using random sampling method in all agricultural fields and some valuable information about the weed infestation was gathered from local formers. The parasitized leaves and various symptoms on horse purslane were critically studied during 20122013 at field sites and photographs of diseased leaves and whole plants were taken using digital camera (Nikon Coolpix S6700 20.1MP). The disease symptoms on leaves and stems were examined as round to oval straw colored spots with maroon margins. The diseased plants and propagules were collected randomly into sterilized polythene bags and brought to the laboratory for the extensive study on symptoms, isolation and pathogenicity of the organism (s) involved in leaf spot disease. The disease symptoms on leaves and stems and other plant parts were critically examined in plant pathology laboratory, Department of Botany, Andhra University, Visakhapatnam.

\section{Isolation and identification of fungal pathogens}

The diseased leaves were washed thoroughly in running tap water to remove soil particles and the infected portions of the leaves were cut into $1.01 .5 \mathrm{~cm}$ fragments. The pieces were surface sterilised by $70 \%$ ethyl alcohol for 1-2 minutes and then rinsed in sterile distilled water for three to four times. Finally the leaf bits were rinsed in $0.01 \%$ mercuric chloride for 1 or 2 minutes fallowed by washing with sterile autoclaved double distilled water for 2 or 3 times. These fragments were transferred on to Czapek's Dox Agar (CZA) and Potato dextrose agar (PDA) plates supplemented with $1 \%$ streptomycin sulphate (antibiotic) under sterile conditions in an inoculation chamber. After inoculation plates were incubated at $26 \pm 2^{\circ} \mathrm{C}$ for 21 days on a $12 \mathrm{hrs}$ light/dark photoperiod. The isolates were purified during the initial growth of fungal colonies on inoculated leaf lesions on the surfaces of agar media. The isolates were examined by the staining techniques and diagnostic characteristics of the isolates were examined under light microscope. The identification features of each isolates such as colony diameter, colour, texture, sporulation, secondary metabolites, the shape and sizes of conidiophores and conidia were carefully studied. Identification of the fungal isolates was made 
with help of the relevant literature (Barnett, 1960; Barron, 1968; Booth, 1977; Domsch et al., 2007; Ellis, 1971, 1976; Gilman, 1957; Holliday, 1993; Nagamani et al., 2006; Sivanesan, 1987; Sutton, 1980; Simmons, 1986; Mitchell, 1988; Aneja and Kaushal, 1998; Aneja et al., 2000; Akhtar et al., 2013).

\section{Inoculation of green house plants to test host specificity}

\section{Spore harvesting}

Conidia and mycelium production was carried out on young (two wk old) sporulated cultures of the isolates in aseptic conditions. The finest spore inocula $\left(10^{4}\right.$ to $10^{6}$ spores $/ \mathrm{ml}$ ) were made using sterilized spatula by flooding the plates with sterile $20 \mathrm{ml}$ distilled water and then scraping the mycelial mass slowly for conidial suspension. The suspension was then filtered through sterile, muslin cloth folded in four layers and the final inoculum was taken into $100 \mathrm{ml}$ conical flasks containing sterile distilled water mixed with $0.02 \%(\mathrm{v} / \mathrm{v})$ Tween 20 (Merck). The inoculum concentration was adjusted at $5 \times 10^{4}$ spores $/ \mathrm{ml}$ using Improved Neubauer haemocytometer (Depth $=0.1 \mathrm{~mm}$ ) for inoculation of test plants.

\section{Growing test plants in green house}

Seeds and seedlings of horse purslane were collected from agricultural fields during the field study. The collected seeds were dried and maintained healthy without any contamination. The plants for further studies were grown by sowing the seeds in $25 \times 15 \mathrm{~cm}$ diameter plastic pots containing sterilized black soil. The pots containing seedlings of weed plants were maintained at $25-30^{\circ} \mathrm{C}$ on wood stand in a green house with a $12 \mathrm{hrs} \mathrm{light/dark} \mathrm{photoperiod.} \mathrm{For} \mathrm{host} \mathrm{range}$ studies test plants were maintained in replicates along with control plants. The test plants growing in aseptic greenhouse conditions were watered daily and fertilized with farmyard manure when required. Infected plants observed at pre-inoculation stage were avoided from pathogenicity test.

\section{Inoculation of healthy test plants}

The test plants with healthy, young and greenish leaves were used for the spore inoculation of the fungal isolates. Test plants were inoculated using hand sprayer and an optimum spore concentration $\left(5 \times 10^{4}\right.$ spores $\left./ \mathrm{ml}\right)$ was used for spore treatment. Spore inoculum was applied onto the test plants of Trianthema portulacastrum and other crop and weed plants within 2 hours of sunset to avoid drying and to allow for a natural dew period shortly afterwards. Plants were observed at 10 daily after post inoculation and the disease severity was assessed using standard ordinal scale (Ray and Hill, 2012).

\section{Disease intensity (DI)}

Disease intensity of isolates was determined visually based on disease symptoms such as minute spots, expanded leaf spots, necrosis, blight etc. The intensity of infection was determined visually based on the number of infected leaves or area of infected parts or whole plants. The disease intensity on leaf surfaces and the development of symptoms were observed daily. An ordinal disease rating scale (Ray and Hill, 2012) was used for the disease description. Using this rating system, a disease index (DI) was calculated (Chaube and Singh, 1991) per observations made at an interval of 10 days after treatment (DAT) with fungal inoculum. Individual leaf rating was considered to estimate the virulence of the pathogen or agent.

$$
\text { Disease Index }=\frac{\text { Sum of all ratings }}{\text { No. of leaves observed } \times \text { Highest rating }} \times 100
$$

\section{Results}

\section{Morphology of Trianthema portulacastrum L. (horse purslane)}

Morphological and taxonomical identical characters of Horse purslane were examined. The weed plant was a prostrate succulent herb; it has a taproot system with fibrous hairs. Stem - more or less angular, glabrous or pubescent, much branched. Leaves- sub fleshy, obliquely opposite, unequal, broadly obovate, rounded and often epiculate at the apex, cuneate at the base, glabrous leaves, opposite, simple, those of the same pair very unequal in size; stipules small; petiole- $0.5-3 \mathrm{~cm}$ long, dilated and sheathing at the base, pair wise connate into a funnel - shaped sheath. Leaf blade- ovate to obovate, $1-5 \mathrm{~cm} \times 0.5-4.5 \mathrm{~cm}$, entire, purple or green, apex rounded or emarginate, base acute, obtuse or rounded, pinnately veined. Flowers - solitary, sessile, and stalk less almost concealed by the pouch of the petiole (Fig. 1). Flowers solitary, axillary, the lower part hidden by the sheath, bisexual, regular, pale pink rarely 
white, perianth 5-lobed, 4-5 mm long, tube fused with the petiolar sheath, with the 2 pointed bracteoles ; and with stem lobes obtuse with a long dorsal but almost apical mucro; Calyx -lobes ovate and acute. Flowers are pink to rose-purple within, green externally, and hoodlike, with a short horn near the tip. Stamens 10-25, filaments white, glabrous; Ovary superior, turbinate,
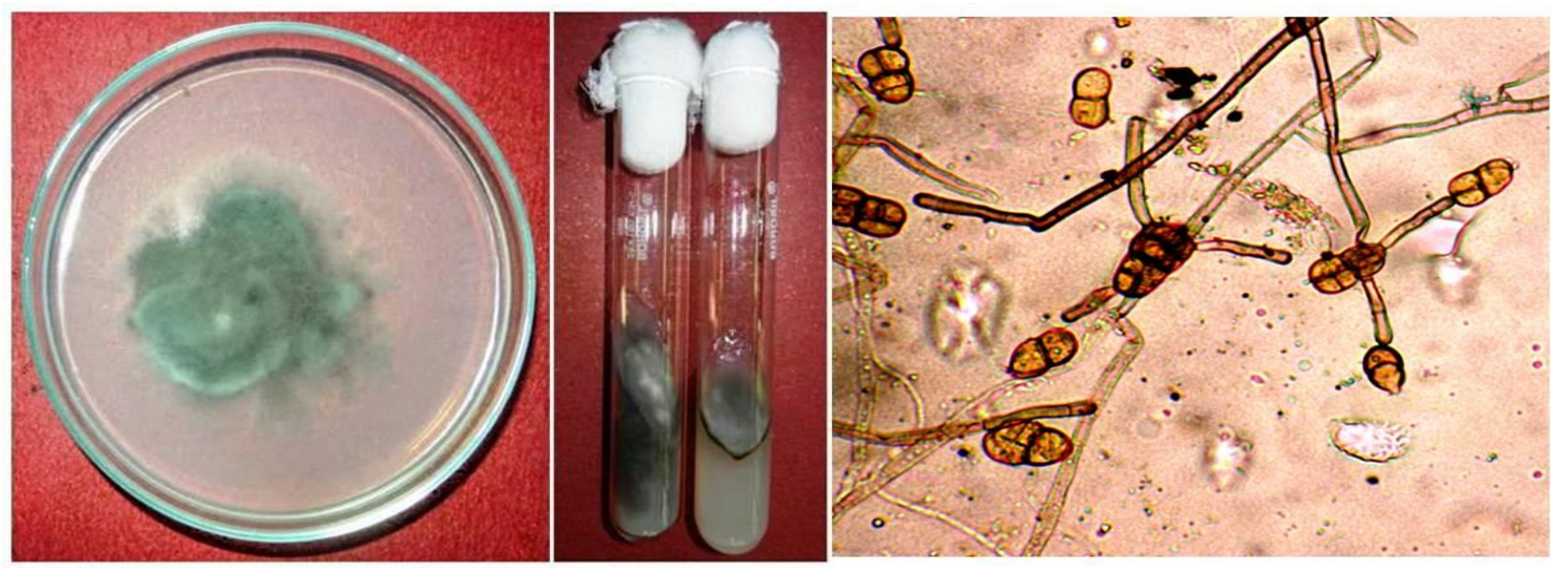

Fig. 1: Pure culture of Gibbago trianthemae on PDA media and sporulation.

\section{Isolation of mycoflora from infected horse purslane}

Foremost, the pathogens associated with weed plant were isolated from leaf lesions of naturally infected horse purslane. A total of six isolates namely Alternaria alternata (Fr.) Keissler., Colletotrichum capsici (Syd.) E.J. Butler \& Bisby., Bipolaris maydis (Y.Nisik. \& C.Miyake) Shoemaker., Curvularia lunata (Wakker) Boedijin., Curvularia tuberculata Sivan. and Gibbago trianthemae Simmons were isolated and identified in cultures of horse purslane parasitized leaf bits (Table 1). The macro and microscopic features of the isolates were examined carefully under light microscope and the diagnostic features of each isolate were examined for their taxonomic identification. The hyphomycetes fungus, Gibbago trianthemae was confirmed by its diagnostic features such as dark grey velvety mold on culture plates, conidiophores stemphylioid, conidia initially solitary, ellipsoid, beakless, pigmented, production of secondary conidia (Fig. 1).

\section{Pathogenicity of isolates on host weed - in vitro test}

An in vitro test was carried out to confirm the pathogenicity of isolates on horse purslane plants growing in green house conditions. The test plants inoculated with spore concentrations $\left(5 \times 10^{4}\right.$ spore/ml $)$ of becoming transversely and longitudinally septate and truncate, 1-celled, style $1.5 \mathrm{~mm}$ long, unilaterally stigmatose throughout its length. Capsule small, $5 \mathrm{~mm} \times$ $3 \mathrm{~mm}$, partly exserted from the persistent perianth, 2-8 seeded. Seeds are small, kidney-shaped, dull reddishbrown to black, and ridged. Seeds are 1.5 - $2.5 \mathrm{~mm}$ long with faint wavy ribs. Seeds are reniform, muriculate and dull black in colour with epigeal germination. each isolate were examined at $24 \mathrm{hrs}$ after the treatment. The phaeodictyoconidial hyphomycetes fungus Gibbago trianthemae infected extremely on leaves and stems of the test plants and produced typical symptoms which were similar to field observations. The fungal pathogen Gibbago trianthemae was reisolated from the infection areas of the inoculated plants and the pathogenicity of the isolate was confirmed on host plant (Table 1). Initially symptoms were pinpoint, black with maroon margins up to $1 \mathrm{~mm}$ in diameter. The lesions became sunken and necrotic after 10-20 days of inoculum spraying. Lesions often coalesced and abscised resulting in premature defoliation. As the lesions elongate they also expanded around the stem. Our observations revealed that Gibbago trianthemae was highly pathogenic to horse purslane as evidenced by the rapid rate of infection and colonization of the host weed (Fig. 2).

The isolates namely Alternaria alternata (Fr.) Keissler., Bipolaris maydis (Y.Nisik. \& C.Miyake) Shoemaker. produced moderate symptoms on leaves of horse purslane at $5 \mathrm{~d}$ after inoculation while the remaining isolates (saprophytic fungi) namely Colletotrichum capsici (Syd.) E.J.Butler \& Bisby., Curvularia lunata (Wakker) Boedijin. and Curvularia tuberculata Sivan considered as non-pathogenic to horse purslane which were failed to produce disease symptoms (Table 1). 
Table 1. Mycoflora isolated from horse purslane weed and their biocontrol potential.

\begin{tabular}{|c|c|c|c|c|c|c|}
\hline $\begin{array}{l}\text { S. } \\
\text { No. }\end{array}$ & Fungal species & $\begin{array}{l}\text { Isolated } \\
\text { parts }\end{array}$ & $\begin{array}{l}\text { Days after } \\
\text { treatment }\end{array}$ & $\begin{array}{l}\text { Disease/Symptoms after } \\
\text { spore treatment }\end{array}$ & $\begin{array}{l}\text { Virulence of the } \\
\text { fungus }\end{array}$ & $\begin{array}{l}\text { Recommendations for } \\
\text { Biocontrol of host weed }\end{array}$ \\
\hline 1 & Alternaria alternata (Fr.) Keissler & Leaves & $20 \mathrm{~d}$ & Minute life spots & Moderate & Suitable to biocontrol agent \\
\hline 2 & Colletotrichum capsici (Syd.) E.J. Butler \& Bisby & leaves & $20 \mathrm{~d}$ & Necrosis & low & Not recommended \\
\hline 3 & Bipolaris maydis (Y.Nisik. \& C.Miyake) Shoemaker & leaves & $20 \mathrm{~d}$ & Necrosis & low & Not recommended \\
\hline 4 & Curvularia lunata (Wakker) Boedijin & leaves & $20 \mathrm{~d}$ & No symptoms & Non-pathogenic & Not recommended \\
\hline 5 & Curvularia tuberculata Sivan & leaves & $20 \mathrm{~d}$ & No symptoms & Non-Pathogenic & Not recommended \\
\hline 6 & Gibbago trianthemae Simmons & Leaves & $20 \mathrm{~d}$ & Leaf spot, stem wilt & High & Highly recommended \\
\hline
\end{tabular}
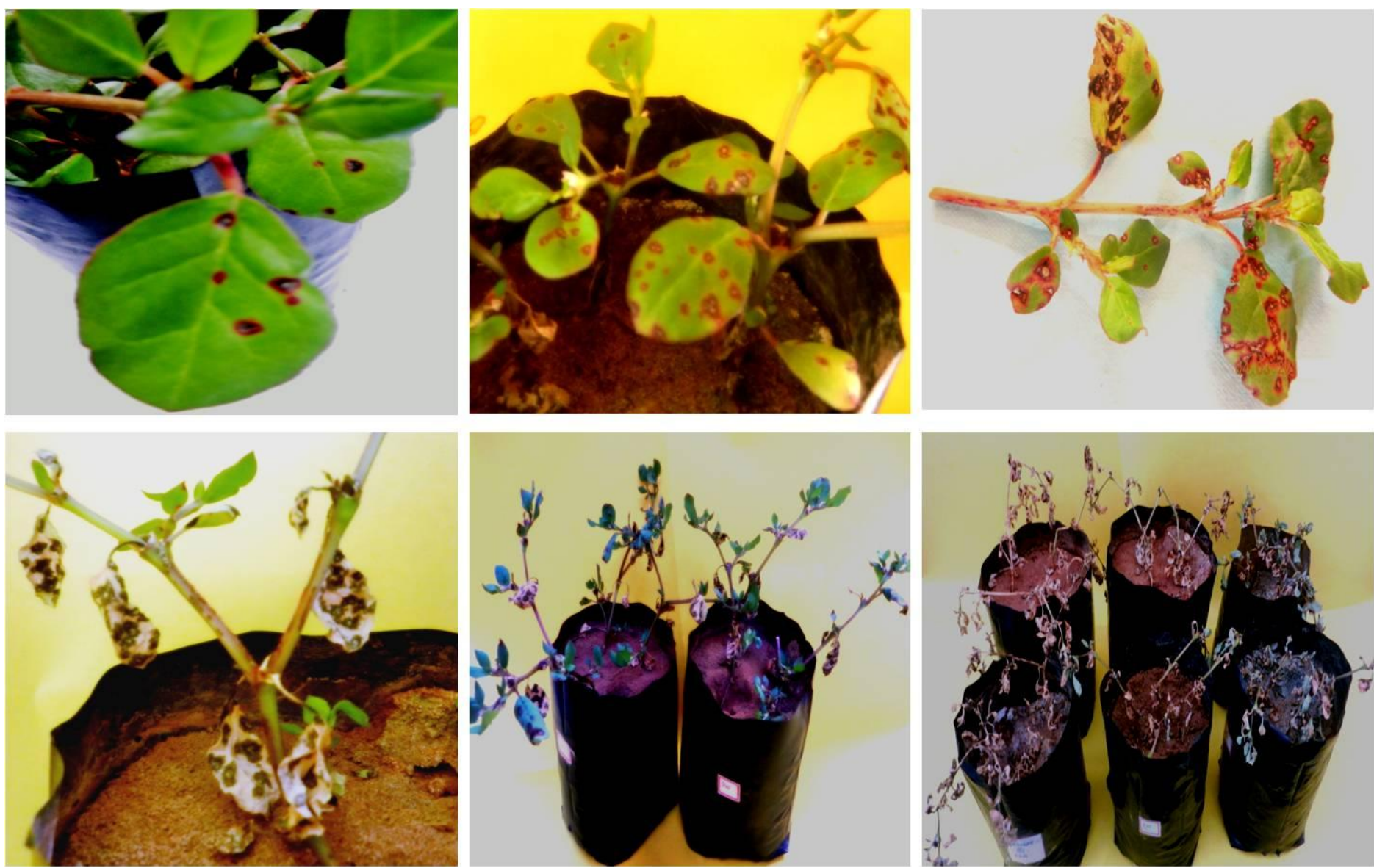

Fig. 2: Biocontrol potential of Gibbago trianthemae on horse purslane after 30 days of spore treatment. 


\section{Host specificity of Gibbago trianthemae - in vitro test}

After the conformation of the virulence, the host range of Gibbago trianthemae was tested on some selected plants in vitro. Test plants for host range study were selected based on the economic importance of native species such as crop plants and weeds in study area. The host specificity of the pathogen Gibbago trianthemae was accomplished on 20 plants species of 12 families includes 7 weed plants and 13 crop plants. Weed species namely Trianthema portulacastrum L. (Aizoaceae) - the host weed, Commelina benghalensis L. (Commelinaceae), Cyperus rotundus L. (Cyperaceae), Crotalaria verrucosa L.(Fabaceae), Digera muricata (L.) Mart. (Amaranthaceae), Sida cordifolia L. (Malvaceae), and Ipomoea pestigridis $\mathrm{L}$. (Convolvulaceae) and crop plants include Zea mays L. (Poaceae), Eleusina coracana Gaertner (Poaceae), Cajanus cajan (L.) Millsp. (Fabaceae), Vigna mungo (L.) Hepper (Fabaceae), Solanum melongena L. (Solanaceae), Abelmoschus esculentus (L.) (Moench) (Malvaceae), Lycopersicon esculentum Miller. (Solanaceae), Capsicum annuum L. (Solanaceae), Arachis hypogaea L. (Fabaceae), Sesamum indicum L. (Pedaliaceae), Amaranthus viridis L. (Amaranthaceae), Brassica oleraceae L. (Brassicaceae) and Spinacia oleraceae L. (Chenopodiaceae) were used for host range studies of the pathogen.

After spore treatment the infection caused by Gibbago trianthemae examined only on horse purslane weed. The test revealed that the isolate Gibbago trianthemae causes extensive damage to host plant (horse purslane) only and all of the 19 other plant species tested were immune to the pathogen. Typical symptoms produced by Gibbago trianthemae were observed on the surfaces of leaf and stem parts of the horse purslane. The initiation of the disease with pinpoint maroon colored spots was started on the superficial areas of leaves and stems of the test plants at $3 \mathrm{~d}$ after post inoculation. A total of $50 \%$ test plants of horse purslane were infected within 20 days of spore treatment. Disease severity was visually evaluated using ordinal scale based on disease symptoms appeared on foliage and the intensity of infection was measured in terms of percent disease index. The percent disease index (PDI) after 20 days was significantly increased $(69.12 \pm 2.94)$ and the early growth stages of the weed were favourable to infection of the pathogen $(p<0.05)$. The maintenance of humidity in growth chambers, where test plants treated with spore inocula plays crucial for the germination of conidia on leaf surfaces. After germination of conidia the pathogen $G$. trianthemae interferes with host tissue and causes severe wilting and chlorosis on host weed within 30 days of inoculation. The light microscopic observations revealed the infection of $G$. trianthemae on foliage of host weed. Defoliation of the weed followed by mortality was significantly high $(94.56 \pm 2.82)$ at 50 days of post inoculation (Fig. 2). No symptoms were visible on other weed plant species such as Commelina benghalensis L., Cyperus rotundus L., Crotalaria verrucosa L., Digera muricata (L.) Mart., Sida cordifolia L. and Ipomoea pestigridis L. inoculated with $5 \times 10^{4}$ spores $/ \mathrm{ml}$ concentration of Gibbago trianthemae. The crop plants include Zea mays L., Eleusina coracana Gaertner, Cajanus cajan (L.) Millsp., Vigna mungo (L.) Hepper, Solanum melongena L., Abelmoschus esculentus (L.) Moench, Lycopersicon esculentum Miller., Capsicum annuиm L., Arachis hypogaea L., Sesamum indicum L., Amaranthus viridis L., Brassica oleraceae L. and Spinacia oleraceae L. were also not infected by the pathogen and they were consider as resistant to the isolate.

\section{Macro and microscopic study on Gibbago trianthemae Simmons}

Reisolation from diseased horse purslane leaves on PDA plates yielded $G$. trianthemae Simmons, whose identity was confirmed by relevant literature (Simmons, 1986; Mitchell, 1988; Aneja and Kaushal, 1998; Aneja et al., 2000; Akhtar et al., 2013). The growth of the fungi from diseased spots inoculated on potato dextrose agar was initiated within three days in culture plates. After approximately 5 to 7 days of incubation dark grey velvety mold growth was observed on culture plates. The observations under a light microscope by staining of mycelial fragments confirmed that conidiophores of the isolated fungus were stemphylioid in general appearance, simple, pale straw colored with 1-4 transeptate and very slightly swollen at apex. Conidiophores solitary or 2-4 loosely fasciculate, erect, rarely distantly branched, simple with a single apical conidiogenous locus, then often proliferating by means of a secondary conidiophore that arises immediately bellow the apical cell of the existing conidiophores; septate, slightly pigmented. Conidia initially solitary, ellipsoid, beakless, pigmented, becoming transversely and longitudinally septate; with apical cells swelling slightly and producing secondary conidia similar to initial ones. Conidia were clear pale yellow brown, smooth, broadly ellipsoid to broadly sub ovate-ellipsoid, 
having 1-4 complete or partial transverse septa (Fig. 1). On the basis of these morphological and cultural characteristics the isolated pathogen was identified as Gibbago trianthemae Simmons, a phaeodictyoconidial hyphomycetes fungus.

\section{Discussion}

Weeds are one of the major threats to the natural environment. They are destroying native habitats, threatening native plants and animals and choking our natural systems. Directly or indirectly weeds reduce production of many crops in India. Weeds are the most significant of the economic and environmental pests, and they are the target of much of the pesticides applied throughout the world. For instance, herbicides comprise $47 \%$ of the world agrochemical sales, and insecticides 29\% (Woodburn, 1995). The major methods of pest control can be grouped into three categories of (1) physical control, (2) chemical control and (3) biological control. These broad categories, in turn, can be combined into integrated pest management (IPM), integrated crop and pest management (ICPM). DeBach (1964) defined biological control as "the action of parasites, predators, or pathogens in maintaining another organism's population density at a longer average than would occur in their absence". Biological control is now being considered for an increasing number of crops and managed ecosystems as the primary method of pest control. One reason for its growing popularity is its record of safety during the past 100 years considered as the era of modem biological control (Waage and Greathead, 1988).

Horse purslane causes heavy losses to agriculture (Aneja et al., 2000; Balyan and Bhan 1986; Saeed et al., 2010; Simmons, 1986). Balyan and Malik (1989) reported that horse purslane is a strong competitor, reducing the yield of mung bean by 50 to $60 \%$ when left untreated. Significant losses in maize, soybean and peanut yield are also attributed to this weed (Grichar, 1993 and 2008; Hazra et al., 2011; Saeed et al., 2010). Allelopathic growth inhibition of crop plants from horse purslane infestation has also been reported (Sethi and Mohnot 1988). Umarani and Selvaraj (1995) reported on the negative allelopathic effects of extracts of horse purslane on seed germination, seedling vigour, and productivity in soybeans. High seed production and short dormancy allow the mature horse purslane seed to germinate rapidly, thereby producing multiple generations in a single season. It is currently controlled mechanically and by the application of pre and post -emergence herbicides such as acifluorfen, alachloral, atrazine, bentazon, fluchloralin, fomesafen, paraquat and pyrivate. But due to increasing global concern about pesticide residues in the biosphere and public demand for pesticide free food, exploitation of microorganisms especially plant pathogenic fungi is now emerging as an effective and eco-friendly alternative to conventional methods of weed control (Aneja, 2009; Aneja and Kaushal, 1998; Charudattan, 1991). Biological control of weeds has advantages over mechanical and chemical methods of weed control, as unlike chemical weedicides, these can be specific to the weed and do not lead to residue problems and accumulation of toxic pollutants in the soil or underground water (Hasan, 1980). Mechanical means of weed control is time consuming and has become labour intensive. Biocontrol agents are generally perceived by the public to be more environmentally friendly and safer for users and consumers.

The increased and indiscriminate use of herbicides to control weeds has resulted in herbicide resistance and environmental pollution. Alien plant problems are increasing worldwide, and biocontrol offers the only safe, economic, and environmentally sustainable solution. Mycoherbicides are primarily attractive because they can be weed specific, have low environmental impact, and are often cost effective (TeBeest et al., 1992). Natural infection on Trianthema portulacastrum L., commonly known as horse purslane was identified at localities of Visakhapatnam District where the interference of weed was abundant. During the field study distinct foliar disease symptoms were identified on the leave surfaces and the infection of the disease was severe at mature stage. The causal agent of leaf spot disease, Gibbago trianthemae was isolated from diseased weed plant and the pathogenesis, host specificity and Disease severity of the isolate was examined to evaluate the mycoherbicide potential of the pathogen. The characteristic feature of the isolate was examined by micro and macroscopic observations and the isolate was confirmed as Gibbago trianthemae Simmons, a hyphomycetes fungus. Gibbago trianthemae on Trianthema portulacastrum is a new record for India (Aneja and Kaushal, 1998) and second for the world. Earlier it was described from the USA, Cuba and Venezuela as a new phaeodictyoconidial genus of Hyphomycetes (Simmons, 1986). Between 1989 and 1998 a series of surveys of plant pathogenic fungi associated with naturally infected horse purslane were conducted in the states of Haryana and Punjab. Infected 
leaves collected from various sites, yielded a species of Gibbago, identified as Gibbago trianthemae Simmons, a phaeodictyoconidial hyphomycetes fungus reported on horse purslane for the first time in India. Pathogenicity of some fungal pathogens on horse purslane was studied in earlier; the species of fungal pathogens namely Cercospora trianthemae (Chiddarwar,1962), Drechslera (Exserohilum) indica (Bipolaris indica) (Rao and Rao, 1987; Taber et al., 1988), Colletotrichum gloeosporioides (Darshika and Daniel, 1992), Fusarium oxysporum (Darshika and Daniel, 1992; Ray and Lakshmi, 2013), Fusarium semitectum (Darshika and Daniel 1998), Alternaria alternata (Bohra et al., 2005; Gupta and Mukerji, 2001; Ray and Lakshmi, 2013), Paecilomyces varioti Bain. (Babu et al., 2004), Myrothecium verrucaria (Albertini and Schwein) Ditmar. Fr., (Boyette and Abbas, 2001), Phoma herbarum Westendorp (Ray and Lakshmi, 2013), Fusarium chlamydosporum Wollenw. \& Reinking (Aneja et al., 2014) and Gibbago trianthemae Simmons (Simmons, 1986; Mitchell, 1988; Aneja and Kaushal, 1998; Aneja et al., 2000; Akhtar et al., 2013) have been identified around the world, of these Gibbago trianthemae have shown potential to control of this weed.

\section{Conclusion}

Biological control pertains to the deliberate use of living agents (natural enemies) to reduce populations of undesirable species (weeds and insect pests) with minimal nontarget effects. The term mycoherbicide usually refers to an indigenous fungus applied in an inundative manner to control native weeds. The inundative method involves application of sufficiently high levels of inoculum to the weed population, under conditions that favour disease onset, to quickly create a disease epidemic among plants. The organism that suppresses the pest or pathogen is known as Biological control agent (BCA). Our in vitro study exposed the pathogenicity of the isolate, Gibbago trianthemae which causes leaf spot and blight disease on Trianthema portulacastrum L. (Horse purslane). The study revealed that Gibbago trianthemae is highly pathogenic to horse purslane as evidenced by the rapid rate of infection and colonization of the host. The test plants inoculated with $5 \times 10^{4}$ spores $/ \mathrm{ml}$ concentration were found that the weed was highly susceptible to Gibbago trianthemae. Our findings suggested the foliar pathogen Gibbago trianthemae may useful as a mycoherbicide to the control of host weed (Trianthema portulacastrum). We reported the primary information on pathogenicity of Gibbago trianthemae against horse purslane and the extensive studies on host range, the host-pathogen interaction, infection process, growth and sporulation, mass culture and compatibility with various pesticides were needed for the development of mycoherbicide using Gibbago trianthemae. Furthermore, the extensive work is needed to develop mycoherbicide product using Gibbago and the feasibility of the pathogen should be tested at field conditions.

\section{Conflict of interest statement}

Authors declare that they have no conflict of interest.

\section{Acknowledgement}

Author thankful to University Grants Commission (UGC), New Delhi, Government of India, for financial support to carried research for sustainable agriculture by controlling alien weeds in India.

\section{References}

Akhtar, K. P., Sarwar, N., Saleem, K., Ali, S., 2013. Gibbago trianthemae causes Trianthema portulacastrum (horse purslane) blight in Pakistan. Australas. Plant Dis. Notes. 8(1), 109-110.

Aneja, K. R., Kaushal, S., 1998. Occurrence of Gibbago trianthemae on horse purslane in India. J. Biol. Control. 12,157-159.

Aneja, K. R., Khan, S. A., Kaushal, S., 2000. Management of horse purslane (Trianthema portulacastrum L.) with Gibbago trianthemae Simmons in India. In: Proceedings of the $10 \mathrm{t}^{\mathrm{h}}$ International Symposium on Biological Control of Weeds (Ed.: Spencer, N. R.), Montana State University, Bozeman, Montana, USA. pp.27-33.

Aneja, K.R., 2009. Biotechnology: An alternative novel strategy in agriculture to control weeds resistant to conventional herbicides. In: Antimicrobial Resistance from Emerging Threats to Reality (Eds.: Lawrence, R., Gulati, A. K., Abraham, G.). Narosa Publishing House, New Delhi. pp.160-173.

Aneja, K.R., Kumar, V., Sharma, C., 2014. Leaf-spot disease of Trianthema portulacastrum - A new record from world. J. Innovat. Biol. 1(2), 112-116.

Babu, R. M., Sajeena, A., Seetharaman, K., 2004. Paecilomyces varioti as bioherbicide on Trianthema portulacastrum (L.) - Anew host record. J. Mycol. Plant Pathol. 34, 142-143. 
Balyan, R. S., Bhan, V. M., 1986. Emergence, growth, and reproduction of horse purslane (Trianthema portulacastrum L.) as influenced by environment conditions. Weed Sci. 34, 516-519.

Balyan, R.S., Malik, R.K., 1989. Control of horse purslane and barnyard grass with post-emergence herbicides in mungbean (Vigna radiata). Indian J. Weed Sci. 37, 695-699.

Barnett, H. L., 1960. Illustrated Genera of Imperfect Fungi. $2^{\text {nd }}$ Edn. Burgess Publishing Company, Minneapolis, MN.

Barron, G. L., 1968. The Genera of Hyphomycetes from Soil. The Williams \& Wilkins Company, Baltimore, U.S.A.

Bohra, B., Vyas, B.N., Godrej, N.B., Mistry, K.B., 2005. Evaluation of Alternaria alternate (Fr.) Keissler for biological control of Trianthema portulacastrum $\mathrm{L}$. Indian Phytopath. 58(2), 184-188.

Booth, C., 1977. Fusarium: Laboratory Guide to the Identification of Major Species. Commonwealth Mycological Institute. Kew, Surrey, U.K.

Boyette, C. D., Abbas, H. K., 2001. New bioherbicides whacks weeds. In: Vegetable Production \& Marketing News (Ed.: Dainello, F. J.). pp.9-10.

Charudattan, R., 1991. The mycoherbicide approach with plant pathogens. In: Microbial Control of Weeds (Ed.: TeBeest, D. O.). Chapman \& Hall, New York. pp.24-57.

Chaube, H. S., Singh, U. S., 1991. Plant Disease Management: Principles and Practices. CRC Press, Boca Raton, Florida.

Chiddarwar, P.P., 1962. Contribution to our knowledge of the Cercospora of Bombay State-III. Mycopathol. Mycol. Applicat. 17, 71-78.

Dangwal, L.R., Singh, A.D., Singh, T., Sharma, A., Sharma, C., 2010. Common weeds of rabi (winter) crops of Tehsil Nowshera district Rajouri (J \& K), India. Pak. J. Weed Sci. Res. 16(1), 39-45.

Darshika, P., Daniel, M., 1992. Changes in chemical content of Adhatoda and Trianthema due to fungal diseases. Indian J. Pharmaceut. Sci. 54, 73-77.

Darshika, S., Daniel, M., 1998. Two new host records of fungi from Gujarat. Indian Phytopathol. 51(2), 206.

DeBach, P., 1964. Biological Control of Insect Pests and Weeds, Reinhold, New York. 844p.

Domsch, K. H., Gams, W., Anderson, T. H., 2007. Compendium of Soil Fungi $2^{\text {nd }}$ Edn. Eching, Germany. 672p.

Ellis, M. B., 1971. Dermatiaceous hypomycetes. Commonwealth Mycological Institute, Kew, Surrey, U.K. 608p.
Ellis, M. B., 1976. More dermatiaceous hyphomycetes Commonwealth Mycological Institute. Kew, Surrey, U.K. 507p.

Gamble, J. S., 1918. Flora of the Presidency of Madras, Vol.1, Adlard \& Son Ltd., London.

Ghani, N., 1929. Khazain-Ul-Advia. ${ }^{\text {st }}$ Edn. New Delhi, Idara Kitabus Shifa (YNM).

Gilman, J. C., 1957. A Manual of Soil Fungi. The Iowa State University Press, U.S.A.

Grichar, W. J., 1993. Horse purslane (Trianthema portulacastrum L.) control in peanut (Arachis hypogaea). Weed Technol. 7, 570-572.

Grichar, W. J., 2008. Herbicide systems for control of horse purslane (Trianthema portulacastrum L.), smellmelon (Cucumis melo L.), and Palmer amaranth (Amaranthus palmeri S. Wats) in peanut. Peanut Sci. 35, 38-42.

Gupta, R., Mukerji, K.G., 2001. Environmental effect on the recurrence of Alternaria alternata on Trianthema portulacastrum. J. Environ. Biol. 22(2), 83-86.

Halder, J., Patra, A.K., 2007. Effect of chemical weedcontrol methods on production of transplanted rice. Indian J. Agron. 52(2), 111-113.

Hasan, S., 1980. Plant pathogens and biological control of weeds. Rev. Plant Pathol. 59, 349-356.

Hazra, D., Das, T. K., Yaduraju, N. T., 2011. Interference and economic threshold of horse purslane (Trianthema portulacastrum L.) in soybean cultivation in northern India. Weed Biol. Manag. 11, 72-82.

Holliday, P., 1993. A Dictionary of Plant Pathogens. Cambridge University Press, New Delhi, India. 369p.

Kirtikar, K.R., Basu, B.D., 2003. Indian Medicinal Plants with Illustrations. $2^{\text {nd }}$ Edn. Vol. 5. Oriental Enterprises, Dehradun.

Mitchell, J. K., 1988. Gibbago trianthemae, a recently described hyphomycete with bioherbicide potential for the control of horse purslane (Trianthema portulacastrum L.). Plant Dis. 72, 354-355.

Mukharjee, D., Singh, R. P., 2005. Effect of micro herbicides on weed dynamics, yield and economics of transplanted rice (Oryza sativa). Indian J. Agron. 50(4), 292-295.

Nagamani, A., Kunwar, I.K., Manoharachary, C., 2006. Hand Book of Soil Fungi. I.K.International Pvt. Ltd.

Nayyar, M.N., Ashiq, M., Ahmad, I., 2001. Manual on Punjab Weeds. Vol. 1. Directorate of Agronomy, Ayub Agricultural Institute, Faisalabad, Pakistan. 52p. 
Peters, B.G., 1955. Soil-inhabiting nematodes. In: Soil Zoology. Butterworth Sci. Publ., London. pp.44-54.

Pullaiah, T., Chennaiah, E., 1997. Flora of Andhra Pradesh. Vol. I. Scientific Publishers, Jodhpur, India.

Rao, A. P., Rao, A. S., 1987. New fungal diseases of some weeds. Indian Botanical Rep. 6, 38.

Rao, A. S., Singh. R. P., 1997. Effect of herbicide mixtures and sequential application on weed in transplanted rice (Oryza sativa). Indian J. Agron. 42(1), 77-81.

Ray, P., Hill, M. P., 2012. Impact of feeding by Neochetina weevils on pathogenicity of fungi associated with water hyacinth in South Africa. J. Aquatic Plant Manag. 50, 79-84.

Ray, P., Lakshmi, S.V., 2013. Evaluation of indigenous fungal pathogens from Trianthema portulacastrum for their relative virulence and host range assessments to select a potential mycoherbicidal agent. Weed Sci. 61(4), 580-585.

Saeed, M., Marwat, K. B., Hassan, G., Khan, A., Khan. I. A., 2010. Interference of horse purslane (Trianthema portulacastrum L.) with maize (Zea mays L.) at different densities. Pak. J. Bot. 42, 173179.

Sethi, A., Mohnot, K., 1988. Allelopathic influence of leaf extracts of Trianthema portulacastrum on germination and growth of moth bean, Vigna aconitifollus. J. Curr. Biosci. 5, 61-63.

Simmons, E. G., 1986. Gibbago, A new phaeodictyo- conidial genus of hyphomycetes. Mycotaxon. 27, 107-111.

Sivanesan, A., 1987. Graminicolous species of Bipolaris, Curvularia, Drechslera, Exserohilum and their teleomorphs. Mycol. Papers. 158, 1-261.

Sutton, B. C., 1980. The Coelomycetes: Fungi imperfecta with pycnidia, acervuli and stromata. Commonwealth Mycological Institute, Kew, Surrey, U.K. 696p.

Taber, R.A., Mitchell, J.K., Brown, S.M., 1988. Potential for biological control of weed Trianthema with Drechslera (Exserohilum) indica In: Abstracts Papers, $\mathrm{V}^{\text {th }}$ International congress of Plant Pathology, Kyoto, Japan. p.13.

TeBeest, D. O., Yang, X. B., Cisar, C. R., 1992. The status of biological control of weeds with fungal pathogens. Annu. Rev. Phytopathol. 30, 637-657.

Umarani, R., Selvaraj, J. A., 1995. Studies on the growth and yield of carpet weed (Trianthema portulacastrum L.) as influenced by soybean (Glycine max (L.) Merrill). Indian J. Weed Sci. 27, 209-210.

Waage, J., Greathead, D. J., 1988. Biological Control: Challenges and Opportunities. In: Biological Control of Pests, Pathogens and Weeds: Developments and Prospects (Wood, R. K. S., Way, M. J.). The Royal Society, London. pp.1-18.

Woodburn, L., 1995. Cotton: The Crop and Its Agrochemical Market. Allan Woodburn Association Ltd, Edinburg, U.K. 231p.

\section{How to cite this article:}

Gaddeyya, G., Esteru Rani, G., Ratna Kumar, P. K., 2017. Exploration of a Hyphomycetes fungus for biological control of horse purslane weed in India. Int. J. Curr. Res. Biosci. Plant Biol. 4(7), 102-111.

doi: https://doi.org/10.20546/ijcrbp.2017.407.013 